\title{
The Life History of Monostroma fuscum var. splendens*
}

\author{
by Masakazu TATEWAKI**
}

Received September 9, 1963

Large quantities of Monostroma fuscum var. splendens (Rupr.) Rosenvinge were found washed ashore at Shikuzushi and Etomo, Muroran, Hokkaido in May of 1959 and 1960. According to Nakamura this plant usually grows on stones or concrete blocks at depths of two or three meters in the area of Muroran. The cultures were grown in Schreiber's solution and kept near the north-east window, at room temperature $\left(18^{\circ}\right.$, on an average, in summer and $7^{\circ}$ in winter).

The swarmers begin to form at the upper margin of the frond extending gradually inwards. Microscopical examination shows that the formation of the swarmers occurs in cells which are 3-6 cells inside from the outer edge of the frond (Fig. 1-4). The fertile parts can be easily distinguished by their yellowish-green or yellowishbrown color. The swarmers are liberated one by one through pores opening on the same side of the thallus. In surface view these pores are clearly round (Fig. 15) as in the case of Ulva. There are three kinds of the swarmers, i.e., zoospores, female and male gametes. The sexual plants are dioecious, and no morphological difference is found between the zoospore-bearing plants and the gamete-bearing plants. Each sporangium generally produces 16-32 zoospores (Figs. 1-2 and 1-3), and eac hgametangium produces $32-64$ gametes.

\section{Gametes and their movement}

The gametes have an elongated pear-shaped or fusiform body with two flagella $(12.0-13.6 \mu$ in length) at the anterior end; their protoplast contains one chloroplast with a pyrenoid and an eye-spot in the posterior part (Figs. 2-1 and 2-2). Sexual reproduction is isogamous; there is no significant difference in size between the two kinds of gametes, measuring 4.5-7.6 $\mu \times 1.5-3.7 \mu$, average, $6.06 \mu \times 2.65 \mu$. The gametes swim very rapidly for 30-60 minutes after liberation from the gametangium; they are positively phototactic, but towards the end of the swarming period they become sluggish in their movement and finally settle down on the substratum. Parthenogenesis is a common feature in the gametes of this species.

By mixing both kinds of gametes, two gametes conjugate generally side by side and form a planozygote (Figs. 2-3 and 2-4).

\section{Zygotes and their development}

After sexual fusion, the planozygotes swim actively for 10-20 minutes; they are negatively phototactic and gradually become less active. They finally lose their flagella and settle down on the substratum (Fig. 2-5) and soon form a wall (Fig. $2-6)$. The resting zygotes are spherical, measuring $4.2-5.0 \mu$ in diameter, and they contain two chloroplasts with a pyrenoid and an eye-spot in each. After five days

* This work was reported at the 28th meeting of the Botanical Society of Japan at Okayama University, October 11-15, 1963.

** Botanical Institute, Faculty of Science, Hokkaido University, Sapporo, Japan. 


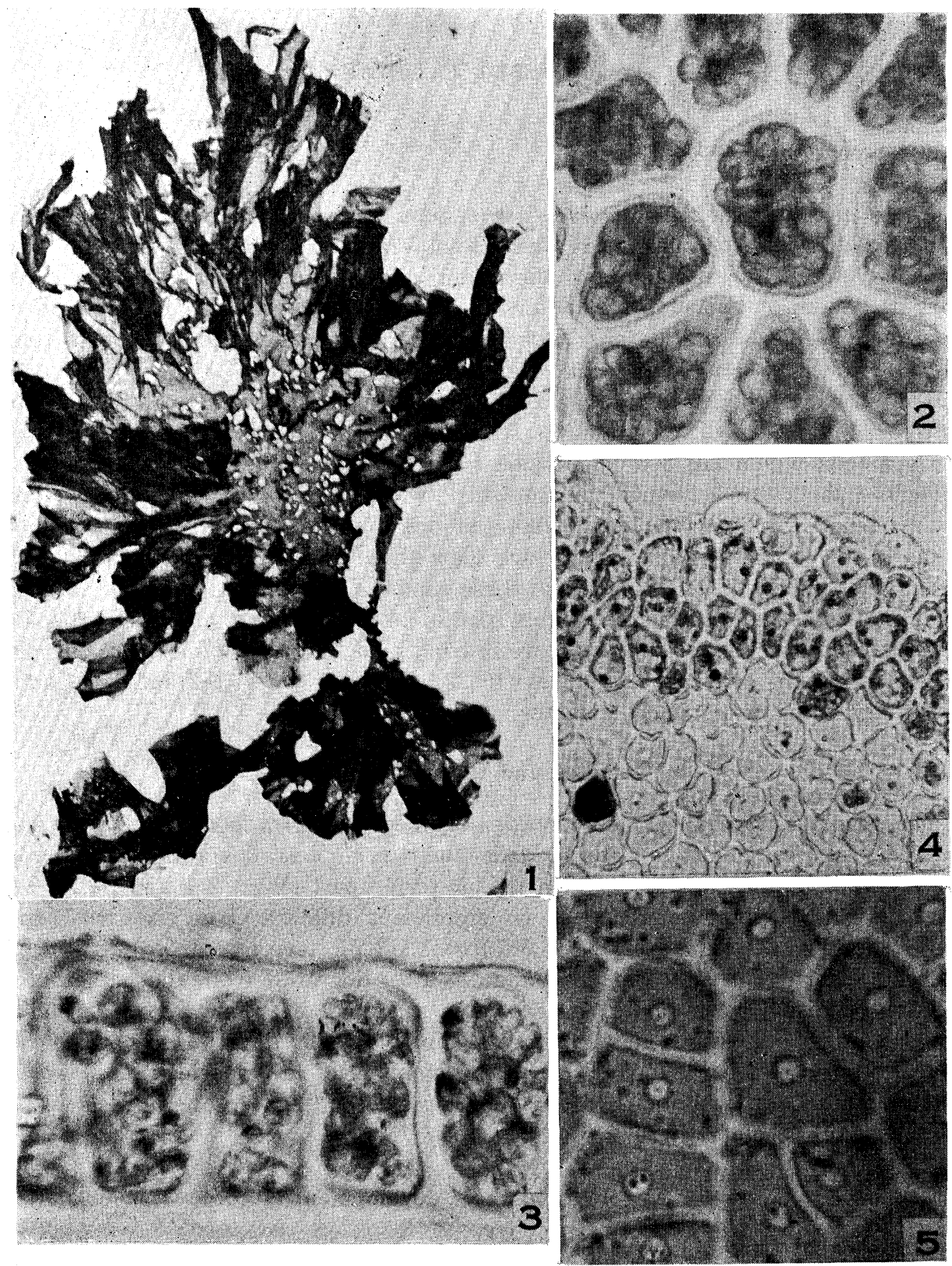

Fig. 1. Monostroma fuscum var. splendens.

1 , a dried specimen, $\times 1 / 4 ; 2$, surface view of the sporangia, $\times 1000 ; 3$, cross section of the sporangia, $\times 1000 ; 4$, surface view of the emptied gametangia with sterile cells at the margin of the frond, $\times 400 ; 5$, surface view of the emptied gametangia with round pores, $\times 1000$. 


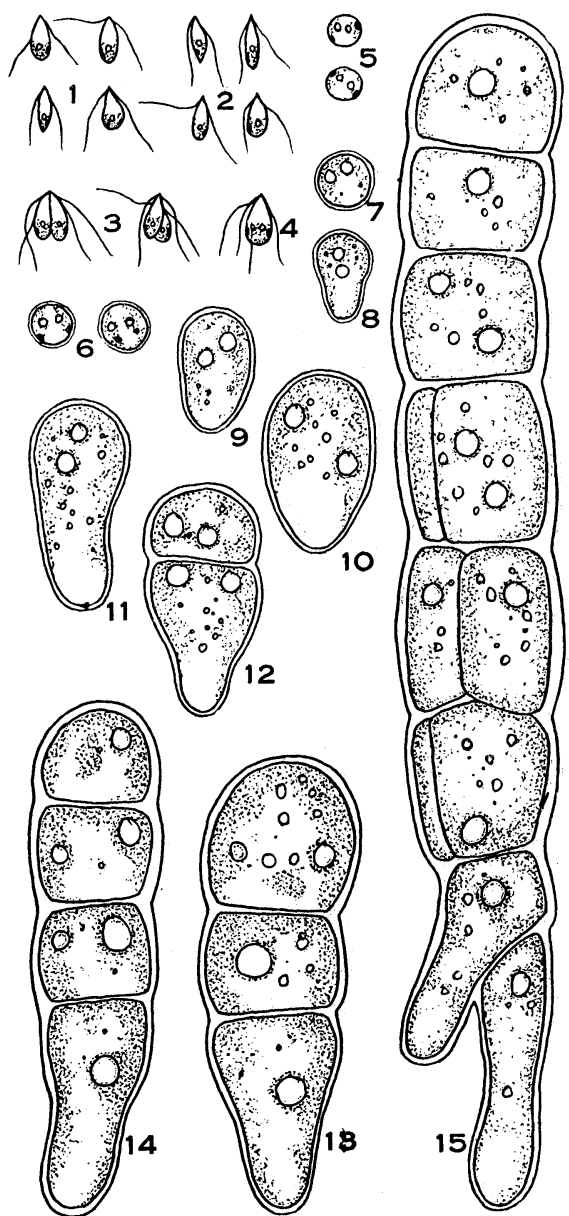

Fig. 2. M. fuscum var. splendens.

1, female gametes; 2, male gametes; 3 , conjugation of gametes; 4, planozygote; $5 \sim 7$, resting zygotes; $8 \sim 11$, germination of zygotes; 12, 2-celled stage; 13 15, further development of zygotes. 13 and 14 , from 2 -week culture; 15 , from 20 -day culture. $\times 675$.

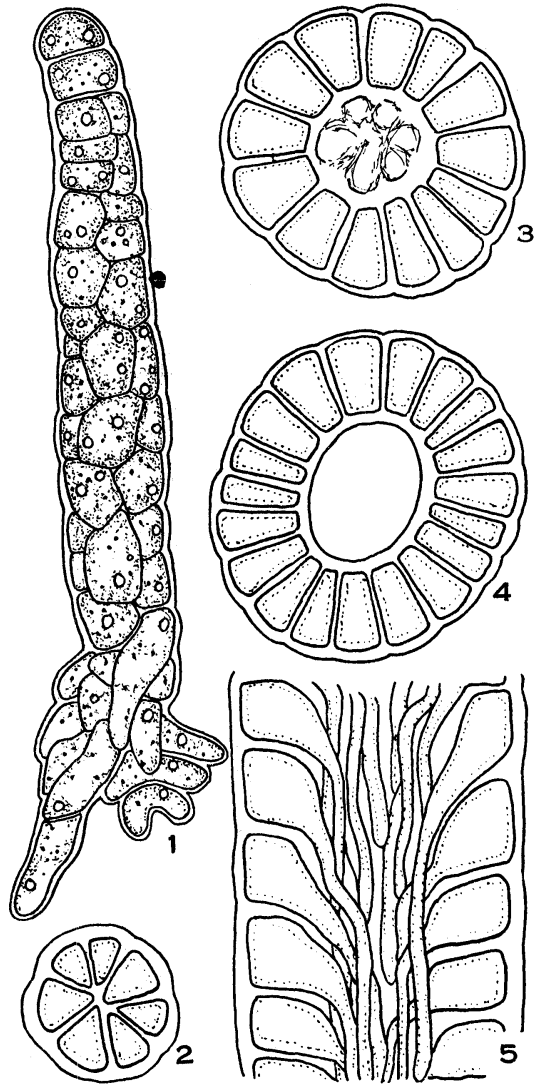

Fig. 3. M. fuscum var. splendens.

1, 25-day culture zygote; 2 4, cross section of the cylindrical and tubular structures; 5 , longitudinal section of the basal part of 50-day culture plant. 2, from 30-day culture; 3, from 40-day culture; 4, from 50-day culture. $\times 270$.

the zygotes measure $6.4-8.0 \mu$ in diameter and the two eye-spots can not be seen (Fig. 2-7). After six days they begin to germinate by pushing out a protuberance (Fig. 2 -8). Then they rapidly increase in size and after ten days divide with a transverse wall into two parts, one of which elongates and forms the primary rhizoid (Figs. 2, $-9 \sim 2-12$ ). By further cell-divisions the zygote becomes a simple filament, consisting of a single row of cells with an elongated rhizoid cell, and in each cell one or two pyrenoids are clearly seen (Figs. 2-13 and 2-14). After about 20 days longitudinal cell-divisions begin to take place in the cells which occupy the central part of the filament (Fig. 2-15). The rhizoid cell begins to branch, giving rise to the secondary rhizoid. After one month the zygote develops into a cylindrical body which stands 
erect from the substratum to a height of $1-3 \mathrm{~mm}$ (Fig. 4-2). After two months the two layers of the cylindrical body separate forming a tubular structure with a cavity in cross section (Fig. 3-4). In such tubular structures a split later takes place near the tip (Fig. 4-3) and they become an expanded membranous frond of a single layer of cells except at the basal part. After about ten months the frond reaches maturity and produces four-flagellated zoospores.

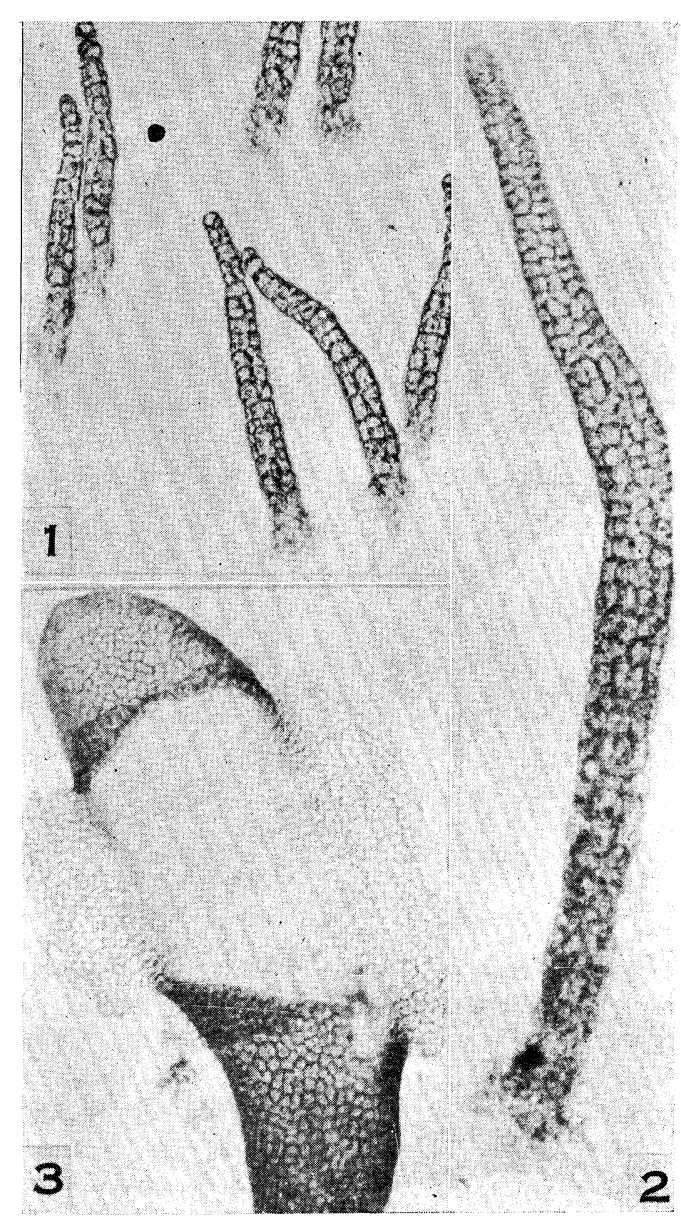

Fig. 4. M. fuscum var. splendens.

1 , sporelings from 20 -day culture, $\times 100 ; 2$, cylindrical frond from 1-month culture, $\times 100 ; 3$, a tubular frond splitted near the tip, $\times 68$.

\section{Zoospores and their development}

The zoospores are elongated pear-shaped, measuring 8.3-12.0 $\mu \times 3.0-4.8 \mu$, average $10.15 \mu \times 4.07 \mu$. They have four flagella $(12.0-13.5 \mu$ in length) at the anterior end and have a chloroplast with a pyrenoid and an eye-spot in the posterior part (Fig. $5-1)$. The zoospores are less active than the gametes; they are positively 
phototactic, but not so conspicuously as the gametes. After swarming for 10-20 minutes, the zoospores lose their flagella and enter into a resting stage and soon form a wall (Figs. 5-2 and 5-3). They become spherical, measuring $4.5-5.4 \mu$ in diameter. After three days the resting zoospores begin to germinate by pushing out a protuberance and at this stage the eye-spot is not recognizable in most of them (Fig. 5-5). The sporelings rapidly increase in size (Fig. 5-6 and 5-7); one-week culture sporelings have divided into two cells by a transverse wall (Fig. 5-8). Within ten days a second transverse division occurs forming an uniseriate filament with an elongated primary rhizoid (Fig. 5-9 and 5-10). After about two weeks longitudinal cell-divisions begin to take place at the central part of the filament (Fig. 5-11), while the rhizoid cell begins to branch, giving rise to the secondary rhizoid. The sporelings develop into an upright cylindrical body and then become tubular. The tubular structures later on open near the tip and form an expanded membranous frond of a single layer of cells. After about ten months the frond reaches maturity and produces biflagellated gametes.

\section{Discussion}

The genus Monostroma comprises those members of the Ulvaceae which, at maturity,

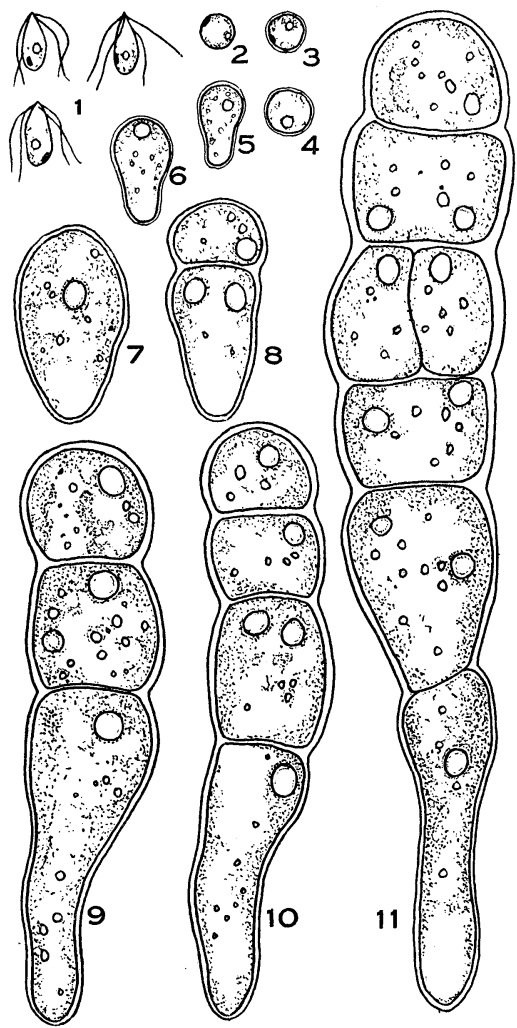

Fig. 5. M. fuscum var. splendens.

1 , zoospores; 2 and 3 , resting zoospores; $5 \sim 7$, germination of zoospores; 8 , 2-celled stage; $9 \sim 11$, further development of zoospores. 7, from 7-day culture; 9 and 10, from 10-day culture; 11, from 2-week culture. $\times 675$.

form an expanded membrane made of a single layer of cells. There are two developmental types of the frond: a) the frond starts as a saccate or tubular structure which later splits and becomes an expanded membranous structure; b) it starts as a one-layered structure from the beginning. In $M$. groenlandicum, however, the frond has a cylindrical habit, never becoming an expanded structure of a single layer of cells.

In the Ulvaceae the organization of the frond is simple, but the shape of the frond varies widely within the same species. The structural characters so far used in classification, do not offer an easy way of distinguishing one species from another. Therefore, the classification of the Ulvaceae should be re-examined using life histories to find more distinctive species characteristics. The life history of Monostroma has been studied by many workers. Kunieda' ${ }^{1)}$ studied Monostroma sp. from Misaki, Japan and reported that "The life history of Monostroma is quite different from those of Ulva or Enteromorpha, in which the plants of the sporophytic generation have the same frond and structure as those of the gametophytic generation. In Monostroma, however, the sporophytic generation is an enlarged zygotic cells, the contents of 
which finally give rise to a number of 4-flagellated zoospores. From the standpoint of life history Monostroma seems to have some relation with Chlamydomonaceae, and it might be justified to place it under a new family Monostromaceae". The above view of Kunieda has been substantiated by Moewus ${ }^{2)}$ on $M$. wittrockii, Yamada \& Saito $^{3)}$ on $M$. angicava and Arasaki ${ }^{4,5)}$ on $M$. latissimum and $M$. nitidum. On the other hand, according to Yamada \& Saito in M. pulchrum, Yamada \& Kanda $^{6}$ ) and Yamada \& Tatewaki ${ }^{7)}$ in $M$. zostericola, the life histories of both species do not agree with the above scheme. In $M$. pulchrum, there is no gametophytic generation. The frond produces 4-flagellated swarmers; the swarmers develop into a unicellular body, forming a number of 4-flagellated swarmers. In $M$. zostericola, Yamada \& Kanda observed that the frond produces only 4-flagellated zoospores which develop into a frond directly, and later Yamada \& Tatewaki found a small gametophytic generation of this species. The frond is the sporophytic generation bearing 4-flagellated zoospores. The zoospores germinate and develop into a small discoid gametophytic generation which forms biflagellated gametes. Therefore, in $M$. zostericola there is an alternation of a large multicellular sporophyte with a small multicellular discoid gametophyte. In $M$. fuscum var. splendens it is impossible to distinguish morphologically the zoospore-bearing plants (sporophyte) from the gamete-bearing plants (gametophyte). The development of the zygotes is exactly similar to that of the zoospores. Such a developmental type is entirely different from those of other species of Monostroma, which were reported until now, and it is identical with that of Ulva or Enteromorpha.

As mentioned above, there are different types of the life history in Monostroma, and the problem of separating the Monostromaceae from the Ulvaceae has not yet been solved satisfactorily and requires further examinations.

\section{Summary}

In Monostroma fuscum var. splendens the sexual plants and the asexual plants are isomorphic. The sexual plants are dioecious and the sexual reproduction is isogamous. The swarmers are liberated through round pores opening on the same side of the thallus. The gametes are elongated pear-shaped or fusiform, having two flagella at the anterior end. The zoospores are elongated pear-shaped, having four flagella at the anterior end. Both gametes and zoospores have one chloroplast with an eye-spot and a pyrenoid in the posterior part; they are positively phototactic. The gametes conjugate generally side by side to form the zygote. Both zygotes and zoospores germinate by pushing out a protuberance after a resting period. The cell divides with a transverse wall into two parts, one of which elongates and forms the primary rhizoid. By successive cell-divisions the germlings (derived from zygotes or zoospores) develop into a simple filament. Then longitudinal cell-divisions take place and the germlings have a cylindrical structure. After two months the germlings attain about $3 \mathrm{~mm}$. in height and develop into a tubular structure with a cavity in cross section. In such tubular structures a split later takes place resulting in an expanded membranous frond of a single layer of cells. After about ten months the plant derived from the zygotes produces 4-flagellated zoospores; the plant derived from the zoospores produces biflagellated gametes.

The type of the life history of $M$. fuscum var. splendens is quite different from those of other Monostroma, which have so far been studied, and it is identical with those of Ulva and Enteromorpha. 
The writer wishes to express his heartfelt thanks to Prof. Y. Yamada, who gave him kind guidance and many facilities, and also thanks to Dr. Y. Nakamura who gave valuable suggestions. And the writer expresses his gratitude to Dr. L. Provasoli, Haskins Laboratories, N. Y. for correcting the manuscript.

\section{References}

1) Kunieda, H., Proc. Imp. Ac. X, 2: 103 (1934). $\quad$ 2) Moewus, F., Arch. Protistenk. 91: 469 (1938). 3) Yamada, Y., and Saito, E., Sci. Pap. Inst. Alg. Res. Hokkaido Imp. Univ. 2: 35 (1938). 4) Arasaki, S., Seibutsu (Life) 1: 281 (1946). 5) Arasaki, S., Suisangaku-zasshi (J. Fisheries) 1: 137 (1951). 6) Yamada, Y., and Kanda, T., Sci. Pap. Inst. Alg. Res. Hokkaido Imp. Univ. 2: 217 (1941). 7) Yamada, Y., and Tatewaki, M., Proc. IX Intern. Bot. Congr. 2: 483 (1959).

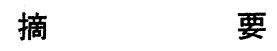

館 脇 正 和: オオヒトエグサの生活史について

緑藻ヒトエグサ属の一種について, 国枝は, 天然に見られる葉体は雌雄異株の配偶体で, 胞子体は微小 な厚膜の単細胞体であることを観察し，この事実に基づいて，配偶体と胞子体が同形のアオサ科からとト エグサ属を分離してヒトエグサ科を新設した。 しかし，ヒトエグサ属の種類の生活史は必ずしも国枝の観 察とは一致していない.

本矿究では，オオヒトエグサの生活史について観察したが，胞子体も配偶体もともに葉状でまったく 同形である。配偶体は雌雄異株，配偶子は雌雄同形で 2 本のべん毛を持ち，遊走子は配偶子より大形で 4 本のベん毛を有する，ともに腿点があり，正の走光性を示す．接合子と遊走子の発生様式は‡ったく同じ で，両者とも静止後，発芽して細長く伸び， はじめは横分裂のみをくり返し数個の一列細胞の発芽体とな り, やがて縦分裂も起こって発芽体は中空の管状葉に発達する. 後に葉体頂部で裂開し一層の細胞層から なる膜状葉となる。本研究では, 培養 10 力月後に成葉を得たが，接合子から発達した葉体には遊走子が， 遊走子からの葉体には配偶子が形成された。すなわら，オオヒトエグサの生活史はアオサ物よび，アオ ノリと同様に同型の世代交代が行なわれていることが観察された。（北海道大学理学部植物学教室） 